\title{
Application of Streaming Effect and Joule Heating Effect of Pulse Current in Crack Healing of Metal Materials
}

\author{
J. Chu, ${ }^{a^{*}}$ G. Li, ${ }^{a}$ and H. Guo ${ }^{b}$
}

a Tianjin Key Laboratory of Information Sensing \& Intelligent Control,

Tianjin University of Technology and Education, Hexi District, Tianjin, 300 222, P.R. China

${ }^{\mathrm{b}}$ Architectural Engineering Department, Wenzhou Vocational \& Technical College,

Wenzhou, Zhejiang, 325 000, P.R. China

\begin{abstract}
\| Abstract
Remanufacture engineering is an emerging industry that saves resources as well as protects the environment. However, cracks on remanufactured components can result in serious trouble. Therefore, in order to avoid unnecessary waste of resources and energy, these cracks should be repaired radically in order to ensure the smooth progressing of the remanufacturing process. Consequently, the crack healing technique of metal materials is very important in the field of remanufacturing. In this study, the U-shape vane stainless steel of a centrifugal compressor which had cracks was processed by pulse current using a high pulse current discharge device, and the influence of the streaming effect and Joule heating effect of pulse current on the crack healing of metal materials was studied, aiming to provide references for the better application of this technology in the remanufacturing field in the future.
\end{abstract}

\author{
\| Keywords \\ Crack, pulse current, remanufacturing, crack healing
}

\section{Introduction}

In recent years, with the proposing of ideas of energy conservation, emission reduction and environmental protection, ${ }^{1}$ the field of remanufacturing has achieved great development. Remanufacturing is a new industry with repairing techniques for the reuse old parts to the greatest extent by repairing them. The key crack repairing technology in the remanufacturing field is to melt cracks by inputting a pulse current to old metal components that have cracks and then concentrating the current on the tip of the crack, which will then melts under the Joule heating effect. ${ }^{2,3}$ Until now, many researchers in China and abroad have carried out relevant studies.

For example, in 2008, Lin et al. ${ }^{4}$ studied the temperature field distribution of crack tips of galvanic sheet metal using finite element method; simulation results indicated that streaming of crack tips of sheet metal could produce Joule heating effect which could melt the crack tips and form craters. In 2009, V. V. Stolyarov ${ }^{5}$ used the instant high pulse current method to improve the thermal fatigue resistance performance of die steel, thus to explore a series of instantaneous dynamics process and accompanied phenomena, and local microstructure evolution rules of metal materials under the effect of pulse current, as well as to discuss the influence rule of pulse current on thermal fatigue behaviours of die steel and its mechanism of action on the improvement of thermal fatigue resistance performance. In 2014, Yu et al. ${ }^{6}$ put forward that the pulse power technol-

*Corresponding author: Dr Jian Chu

email: chu_jian1@sina.com ogy is mainly focused on production and transmission of high voltage, strong current, and high power pulse, which was one of the main subjects of modern high technology and had broad development and application prospects. ${ }^{6}$ This study aimed to analyse the crack arrest and healing of cracks of metal materials using the streaming and Joule heating effect of pulse current.

\section{Experiments}

\subsection{Materials}

In order to further study the crack arrest effect of impulse current discharging technique on different metal material cracks, this study selected U-shaped vane stainless steel as the research material. The chemical composition of the steel was tested using the American Angstrom V-950 spectrometer with a test accuracy of 3-4 PPM. Table 1 shows the chemical composition of the selected material.

Table 1 - Chemical composition of the U-shaped vane stainless steel

\begin{tabular}{l|c|c|c|c|c|c|c}
\hline \multirow{2}{*}{ Material type } & \multicolumn{6}{|c}{ Chemical composition, mass fraction/\% } \\
\cline { 2 - 8 } & $\mathrm{C}$ & $\mathrm{Ni}$ & $\mathrm{Cr}$ & $\mathrm{Mo}$ & $\mathrm{Si}$ & $\mathrm{P}$ & $\mathrm{Mn}$ \\
\hline $\begin{array}{l}\text { stainless steel } \\
\begin{array}{l}\text { Inconel 718 } \\
\text { nickel base }\end{array}\end{array}$ & 0.09 & 11.23 & 16.25 & 2.09 & 0.68 & 0.02 & 1.22 \\
alloy & & & & & & & \\
\hline
\end{tabular}




\subsection{Sample preparation}

The selected U-shaped vane stainless steel was processed into standard tensile samples, which were then lathed with $15^{\circ}$ grooves on both the left and right side. To study the crack arrest effect of strong pulse current on the cracks, we used a linear cutting machine to cut off the cracks and carry out grinding at the port. The size of the samples is shown in Fig. 1.

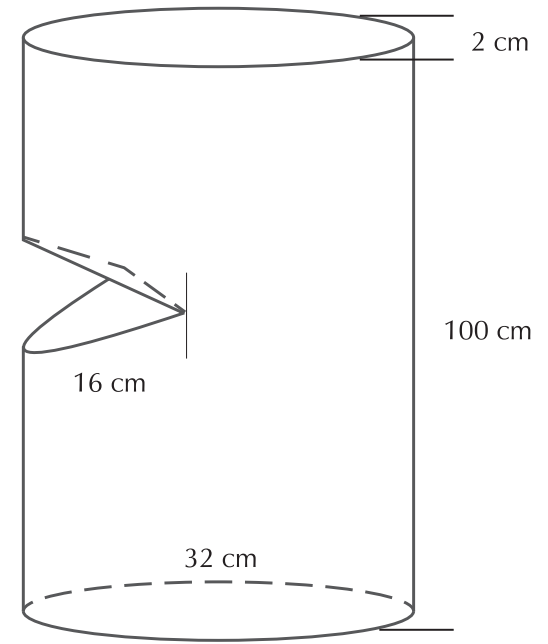

Fig. 1 - Scheme of the size of a sample with cracks

\subsection{Electric pulse processing experiment}

The high pulse current discharging device was the core equipment in the experiment of using pulse current to heal cracks of metal materials, which used high voltage pulse capacitor to store energy and discharge current, thus to produce instant high pulse current.

\subsubsection{Performance tests of pulse current discharging device}

An important component of the pulse current discharging device was the high-voltage switch, which guaranteed the stability of experimental devices. Parameters of the high-voltage switch in this study were as follows: electric potential withstand $12 \mathrm{kV}$, range of working potential 5-10 kV and bearable current range 40-300 kA. The electrode spacing selected in this study was $2.5 \mathrm{~mm}$, $4.5 \mathrm{~mm}$, and $6.5 \mathrm{~mm}$; the correlation curve of different electrode spacing and working electric potential of the switch was calculated under $350 \mathrm{~cm}^{3} \mathrm{~min}^{-1}$, at standard temperature and pressure, of air inflow rate using the main electrode coaxial air inflow method; after that, it was judged whether the working voltage of the switch was within the designed electric potential range. Assuming the air inflow rate was $350 \mathrm{~cm}^{3} \mathrm{~min}^{-1}$ (standard temperature and pressure), the correlation curve of different electrode spacing and working potential of switch is shown in Fig. 2.

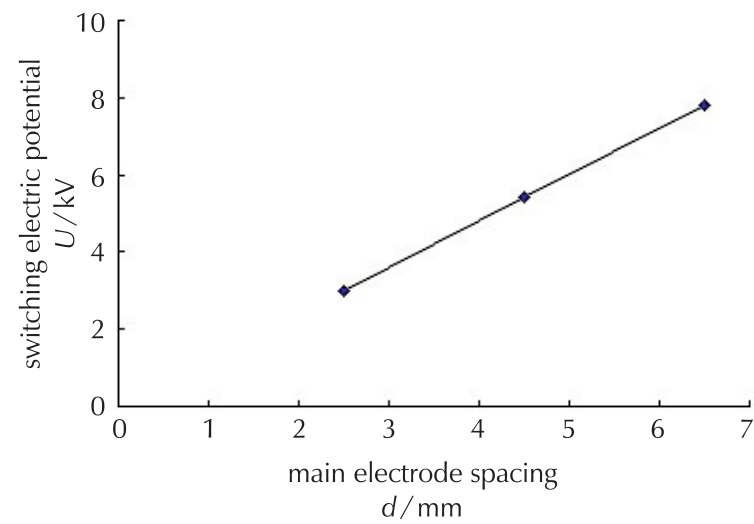

Fig. 2 -Correlation between different electrode spacing and working electric potential of switch under $350 \mathrm{~cm}^{3} \mathrm{~min}^{-1}$ of air inflow rate at standard temperature and pressures

Fig. 2 shows that when the air inflow rate was $350 \mathrm{~cm}^{3} \mathrm{~min}^{-1}$, at standard temperature and pressure, the working potential of the switch was in positive correlation with the main electrode spacing. Moreover, the main electrode spacing was within the original range and the switch potential met the requirement.

\subsubsection{Experimental process of crack healing with pulse current}

Before the experiment, the sample was fixed with screws and insulating fixtures made of nylon plastic; the two ends of the sample were then connected to the discharge circuit using copper electrodes. If technological parameters were high, the conduction of the discharge circuit could instantly melt the crack tips, and the phenomena of flying sparks and huge sound could occur. ${ }^{8,9}$ After discharging, an approximate circular or oval fused hole appeared at the crack tip; melted metal was then solidified around the hole.

\subsection{Microstructure analysis}

\subsubsection{Optical microstructure detection}

After pre-grinding with sandpaper, the sample was mechanically polished and eroded in a $3.5 \%$ nitric acid alcohol solution to reveal its metallographic microstructure. The original austenite grain boundaries of the sample were revealed using a saturated aqueous solution of picric acid. Optical microscopic observation was performed with an optical microscope. In order to calculate the size distribution, five $800 \times$ grain boundary morphology metallographic photographs taken from different angles were selected.

\subsubsection{Microhardness detection}

The microhardness tester with a $\mathrm{MH}-60$ controller was used to test the hardness of the specimen after pulsed discharge. According to the specimen size and material properties, the load was determined to be $200 \mathrm{gf}$ (gram-force, $1 \mathrm{gf}=9.80665 \cdot 10^{-3} \mathrm{~N}$ ) and the loading time 
$15 \mathrm{~s}$. The specimen hardness measurement was performed on 8 points in the crack phase transition zone and the base area, and the average value was selected as the hardness of the specimen.

\section{Results and discussion}

\subsection{Effect of pulse current processing on crack healing}

\subsubsection{Effect of pulse current processing on the macromorphology of crack tips}

The macromorphology of pulse current arresting crack tips is shown in Fig. 3. At the moment of melting, a large swelling amount occurred at high-temperature positions. However, due to the constraint from low-temperature matrix, compressing phenomena occurred inside the crack, which explained the morphology after discharging, shown in Fig. 3. ${ }^{14-15}$ The fused holes that appeared after the pulse current eliminated the stress concentration effect of the crack tips. ${ }^{16-18}$ Crack growth rate reduction was mainly due to two reasons, i.e., the formation of fused holes and the existence of compressive stress field.

In Fig. 3, A is the appearance of prefabricated tensile cracks for stainless steel specimens, which is the phenomenon when the pulse current is concentrated around the crack tip; $\mathrm{B}$ is a dissolved pore formed when the melting material erupts outside the centre after the pulse discharge is completed; $\mathrm{C}$ is the phenomenon of crack healing between the cracks behind two neighbouring dissolved pores.

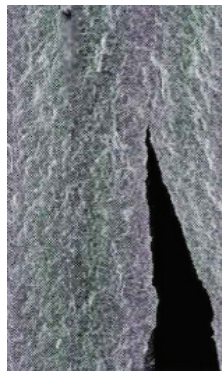

A

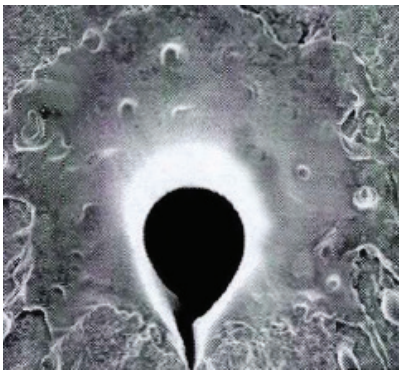

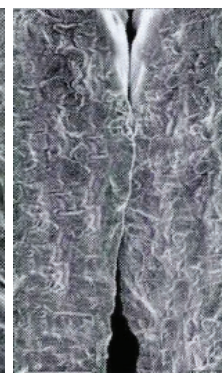

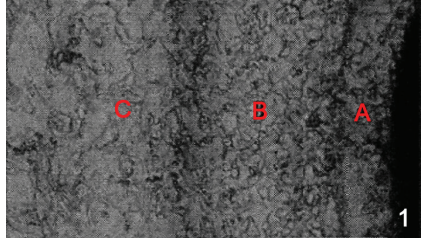

$1: 50 \mu \mathrm{m}$

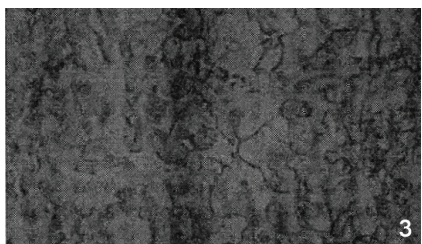

$1: 20 \mu \mathrm{m}$

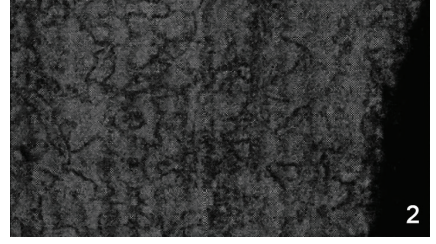

$1: 20 \mu \mathrm{m}$

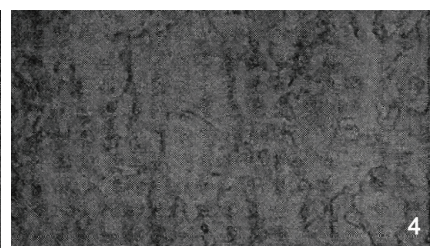

$1: 20 \mu \mathrm{m}$

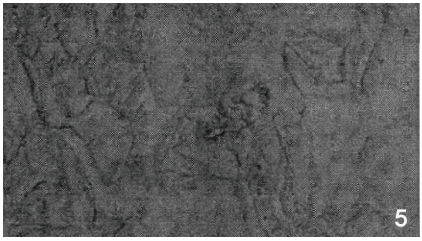

$1: 20 \mu \mathrm{m}$

Fig. 4 - The microstructure under an optical microscope

\subsubsection{Microhardness analysis}

Eight points from the phase change zone and matrix zone of cracks, respectively, were selected for comparison and analysis of microhardness. Fig. 5 shows that the hardness of the phase change zone increased significantly compared with that of the matrix zone, which was because after impulsive discharge strengthening, the tissues around cracks obtained by quenching strengthened the sample. Thus, the phase change zone had higher hardness.

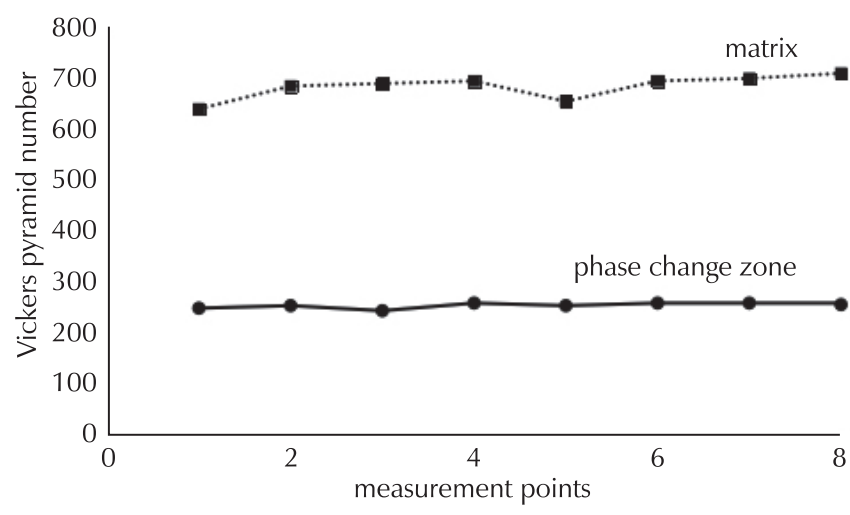

Fig. 5 - Distribution of microhardness

Fig. 4 shows the microscopic morphology after pulse current treatment. A heat-affected zone formed at the crack tip region after pulsed current treatment. Fig. 4 (1) shows the complete morphology, with visible cell dendrites at the cracks. Fig. 4 (2) shows that the junction is made up of equiaxed crystals. Fig. 4 (3) shows that the B domain consists of more uniform equiaxed crystals, which are significantly larger than the ones in Fig. 4 (2). Fig. 4 (4) reflects the area that is less affected by the B area. Fig. 4 (5) is a tensile deformation grain formed by prefabricated tensile cracking, with a large size. 
ature of the damaged part could increase under the effect of pulse current. However, if the temperature exceeded the fusing point of the material, the size of the microcrack could be enlarged, which was not an ideal healing process. Therefore, the input electric energy should have a critical value $W_{\max }$ as well as meet the following requirement:

$$
R \leq W \leq W_{\max }
$$

The sample that had mircrocracks could be taken as a closed system: during pulse current processing, there was only energy exchange between the sample and the environment instead of material exchange. ${ }^{20-22}$ The driving force during the crack healing process was provided by pulse current as transient energy input. ${ }^{23,24}$ Under the effect of streaming and Joule heating effect of pulse current, fast heating and cooling of areas around the cracks appeared, thus it generated pressure stress and the crack surface spacing narrowed. ${ }^{25}$

\subsection{Influencing factors of crack healing under the effect of pulse current}

When the pulse current passed through the metallic conductor, the average temperature of the sample could increase due to the Joule heating effect. The expression of increased temperature $\Delta T$ is:

$$
\Delta T=\frac{\rho j^{2} t}{c d}
$$

In Eq. (2), $j$ refers to current density, $t$ is the action time of the pulse current, $\rho$ is resistivity, $c$ is specific heat capacity, and $d$ is density. The current path could be impeded due to surface-opening cracks. However, the current could bypass the crack tips and choose the shortest path, which could lead to an increase in local current density of the crack tips, and such phenomenon is called streaming around and concentration of current. Eq. (2) indicates that a temperature increase in the crack tips was due to their Joule heating effect being higher than other parts of the sample.

The action time of the current was very short in the pulse current processing and other transformation forms of electric energy could be ignored, thus it could be regarded that all input electric energy transformed into Joule heat. Therefore, the expression of generated Joule heat in the sample under the effect of pulse current is:

$$
Q=\rho j^{2} V t
$$

In Eq. (3), $V$ is the volume of sample.

According to Eqs. (2) and (3), the relationship between average increased temperature of the sample and Joule heat could be obtained and expressed as:

$$
\Delta T=\frac{Q}{c d V}
$$

LRC loop was similar to the discharge circuit, thus the input electric energy $W$ can be expressed as:

$$
W=\frac{1}{2} C U^{2}
$$

In the equation, adjustable parameters of high pulse current discharging device were loop capacitance $(C)$ and capacity charge electric potential $(U)$. As assumed previously, the input electric energy was the same as Joule heat, i.e., it all transformed into Joule heat, when the pulse current passed through the sample, the relationship among average increase temperature, input electric energy and technological parameters could be expressed as:

$$
\Delta T=\frac{W}{c d V}=\frac{C U^{2}}{2 c d V}
$$

Eq. (6) shows that, the main influencing factors of temperature increase of crack tips were technological parameters of materials, physical dimension of samples, and pulse current discharging. Corresponding mechanical property results could be different under different increased temperatures, sizes of melting zone, and microstructure changes. Therefore, the influencing factors of temperature increasing of crack tips were basically the same as those of the crack arrest effect of the pulse current.

\section{Conclusion}

This study applied the streaming around effect and Joule heating effect of pulse current to explore the crack healing in metal materials, and the appearance display was carried out both from the macro and micro perspective. Through the microhardness analysis, it is found that the structure obtained by quenching around the crack after the pulse discharge is an important basis for the strength and toughness of the specimen, and the microhardness of the phase change region is higher. In the experiment, it was discovered that during pulse current processing, circular or oval fused holes are formed at crack tips that can improve the stress state of crack tips, thus achieving the crack arrest and healing effect. In addition, it is found by the study of influencing factors of pulse current healing effect that the main influencing factors are the material and the geometric size of specimens, as well as the pulse current discharge process parameters. When the mechanical properties of the crack tip change with the temperature rise, the melting zone and micro-light structure changes, the factors that affect the temperature rise of the crack tip and the factors that affect the crack cracking effect of the pulse current are basically the same. However, due to the limitation of experimental conditions and resources, this study still has shortages, which need to be improved in the future. 


\section{List of abbreviations and symbols}

C - capacitance

C $\quad$ - specific heat capacity

d - density

j - electric current density

Q - heat

$R \quad-$ critical healing energy

$T$ - temperature

$t \quad-$ time

$U \quad$ - electric potential

$\checkmark \quad-$ volume

W - input electric energy

$W_{\max } \quad$ - maximal healing energy

$\rho \quad-$ electrical resistivity

\section{ACKNOWLEDGEMENT}

This study was supported by Research on a new method for measuring moisture content of starch (KJ1730).

\section{References Literatura}

1. J. Zhang, Y. Lei, F. Liu, J. Zheng, Wind power consumptive problem in the perspective of energy conservation and emission reduction, Advanced Research and Technology in Industry Applications (WARTIA), 2014 IEEE Workshop on. IEEE (2014) 32-35, doi: https://doi.org/10.1109/WARTIA.2014.6976183.

2. J. Yu, H. C. Zhang, D. W. Deng, S. Z. Hao, A. Iqbal, Numerical Calculation and Experimental Research on Crack Arrest by Detour Effect and Joule Heating of High Pulsed Current in Remanufacturing, Chin. J. Mech. Eng. 27 (4) (2014) 745753, doi: https://doi.org/10.3901/CJME.2014.0414.075.

3. R. Bermejo, P. Supancic, I. Kraleva, R. Morrell, R. Danzer, Strength reliability of 3D low temperature co-fired multilayer ceramics under biaxial loading, J. Eur. Ceram. Soc. 31 (5) (2011) 745-753, doi: https://doi.org/10.1016/j.jeurceramsoc.2010.11.031.

4. H. Q. Lin, Y. Zhao, Y. Zhao, L. Han, J. Ma, Q. Jiang, Effect of Pulse Electric Current Stimulation on the Microstructure, Mechanical Properties and Thermal Fatigue Behavior of Casthot-working Die Steel, ISIJ International 48 (2) (2008) 212217, doi: https://doi.org/10.2355/isijinternational.48.212.

5. V. V. Stolyarov, Structure Refinement and Electropulse Current Effect on Mechanical Properties of Shape Memory TiNi Alloy, Mater. Sci. Forum 633-634 (2009) 595-603, doi: https://doi.org/10.4028/www.scientific.net/MSF.633634.595.

6. J. Yu, H. C. Zhang, D. Deng, S. Hao, A. Iqbal, Numerical Calculation and Experimental Research on Crack Arrest by Detour Effect and Joule Heating of High Pulsed Current in Remanufacturing, Chin. J. Mech. Eng. 27 (4) (2014) 745-753, doi: https://doi.org/10.3901/CJME.2014.0414.075.

7. S. Park, S. Choi, Soft-Switched CCM Boost Converters with High Voltage Gain for High-Power Applications, IEEE T. Power Electr. 25 (5) (2010) 1211-1217, doi: https://doi.
org/10.1109/TPEL.2010.2040090.

8. M. Roskosz, M. A. Bouhifd, A. P. Jephcoat, B. Marty, B. O. Mysen, Nitrogen solubility in molten metal and silicate at high pressure and temperature, Geochimica Et Cosmochimica Acta, 121 (6) (2013) 15-28, doi: https://doi.org/10.1016/j. gca.2013.07.007.

9. D. Choi, D. Wang, I.-T. Bae, J. Xiao, Z. Nie, W. Wang, Vilayanur V. Viswanathan, Y. J. Lee, J.-G. Zhang, G. L. Graff, Z. Yang, J. Liu, $\mathrm{LiMnPO}_{4}$ nanoplate grown via solid-state reaction in molten hydrocarbon for Li-ion battery cathode, Nano Lett. 10 (8) (2010) 2799-2805, doi: https://doi.org/10.1021/ nl1007085.

10. Z. Bu, S.-H. Lee, C. M. Brown, D. M. Engelman, C. C. Han, A view of dynamics changes in the molten globule-native folding step by quasielastic neutron scattering, J. Mol. Biol. 301 (2) (2014) 525-536, doi: https://doi.org/10.1006/ jmbi.2000.3978.

11. S. Velazquez-Peña, C. Sáez, P. Cañizares, I. Linares-Hernández, V. Martínez-Miranda, C. Barrera-Díaz, M. A. Rodrigo, Production of oxidants via electrolysis of carbonate solutions with conductive-diamond anodes, Chem. Eng. J. 230 (16) (2013) 272-278, doi: https://doi.org/10.1016/j.cej.2013.06.078.

12. B. Ge, D. S. Ai, C. S. Deng, J. T. Ma, X. P. Lin, Synthesis of $\mathrm{Sr}_{2} \mathrm{Fe}_{1-x} \mathrm{Mn}_{\mathrm{x}} \mathrm{NbO}_{6-\delta}$ Powders and their Stability as Electrode of Solid Oxide Electrolysis Cell, Key Eng. Mater. 512-515 (2012) 1584-1587, doi: https://doi.org/10.4028/www.scientific.net/KEM.512-515.1584.

13. B. Ge, J. T. Ma, D. Ai, C. Deng, X. Lin, J. Xu, $\mathrm{Sr}_{2} \mathrm{FeNbO}_{6}$, Applied in Solid Oxide Electrolysis Cell as the Hydrogen Electrode: Kinetic Studies by Comparison with Ni-YSZ, Electrochim. Acta 151 (2015) 437-446, doi: https://doi. org/10.1016/j.electacta.2014.11.078.

14. J. Zhang, C. Chi, Y. Guan, W. Liu, J. Wu, Simulation of Arc Rotation and Its Effects on Pressure of Expansion Volume in an Auto-Expansion $\mathrm{SF}_{6}$ Circuit Breaker, Plasma Sci. Technol. 18 (3) (2016) 287-291, doi: https://doi.org/10.1088/10090630/18/3/12.

15. G. Wang, Y. H. Wang, Z. L. Gao, Use of steel slag as a granular material: Volume expansion prediction and usability criteria, J. Hazard. Mater. 184 (1-3) (2010) 555-560, doi: https://doi. org/10.1016/j.jhazmat.2010.08.071.

16. H. Waisman, An analytical stiffness derivative extended finite element technique for extraction of crack tip Strain Energy Release Rates, Eng. Fract. Mech. 77 (16) (2010) 3204-3215, doi: https://doi.org/10.1016/j.engfracmech.2010.08.015.

17. L. Bouhala, Q. Shao, Y. Koutsawa, A. Younes, P. Núñez, A. Makradi, S. Belouettar, An XFEM crack-tip enrichment for a crack terminating at a bi-material interface, Eng. Fract. Mech. 102 (2) (2013) 51-64, doi: https://doi.org/10.1016/j. engfracmech.2013.02.023.

18. B. Lin, L. G. Zhang, J. Tong, A crystal plasticity study of cyclic constitutive behavior, crack-tip deformation and crackgrowth path for a polycrystalline nickel-based superalloy, Eng. Fract. Mech. 78 (10) (2011) 2174-2192, doi: https:// doi.org/10.1016/j.engfracmech.2011.04.006.

19. Z. W .Ge, C. Yang, Microfluidic concentration of sample solutes using Joule heating effects under a combined AC and DC electric field ASME 2010, International Conference on Nanochannels, Microchannels, and Minichannels Collocated with, Joint Us-European Fluids Engineering Summer Meeting (2015) 877-883, doi: https://doi.org/10.1115/FEDSM-ICNMM2010-30451.

20. H. Wen, Y. Yu, G. Zhu, L. Jianga J. Qin, A droplet microchip with substance exchange capability for the developmental study of C. elegans. Lab. Chip. 15 (8) (2015) 1905-1911, doi: https://doi.org/10.1039/c4lc01377h. 
21. M. Dragutin, I. Balaž, I Arsenić, A numerical study of synchronization in the process of biochemical substance exchange in a diffusively coupled ring of cells, Open Phys. 11 (11) (2013) 440-447, doi: https://doi.org/10.2478/s11534-013-0221-5.

22. D. Mihailović, V. Kostić, I. Balaž, Lj. Cvetković, Complexity and asymptotic stability in the process of biochemical substance exchange in a coupled ring of cells, Chaos Soliton. Fract. 65 (4) (2013) 30-43, doi: https://doi.org/10.1016/j. chaos.2014.04.008.

23. H. H. Chang, C. L. Lin, J. K. Lee, Load identification in nonintrusive load monitoring using steady-state and turnon transient energy algorithms International Conference on Computer Supported Cooperative Work in Design,
CSCWD 2010, April 14-16, 2010, Fudan University, Shanghai, China (2010) 27-32, doi: https://doi.org/10.1109/ CSCWD.2010.5472008.

24. K. Ishida, T. Yasufuku, S. Miyamoto, H. Nakai, M. Takamiya, T. Sakurai, K. Takeuchi, 1.8 V Low-Transient-Energy Adaptive Program-Voltage Generator Based on Boost Converter for 3D-Integrated NAND Flash SSD, IEEE J. Solid-St. Circ. 46 (6) (2011) 1478-1487, doi: https://doi.org/10.1109/ JSSC.2011.2131810.

25. X. L. Fan, R. Xu, W. X. Zhang, T. J. Wang, Effect of periodic surface cracks on the interfacial fracture of thermal barrier coating system, Appl. Surf. Sci. 258 (24) (2012) 9816-9823, doi: https://doi.org/10.1016/j.apsusc.2012.06.036.

\section{SAŽETAK}

\section{Zacjeljivanje pukotina u metalu pulsnom strujom Jian Chu, ${ }^{a^{*}}$ Gang Li i Hong Guo}

Obnavljanje uređaja i postrojenja pomaže u smanjenju troškova i očuvanju okoliša, ali ozbiljne probleme mogu uzrokovati pukotine na obnovljenim komponentama. Da bi se izbjeglo nepotrebno trošenje energije i sredstava, pukotine se moraju potpuno sanirati.

Radi unaprjeđenja tehnike reparacije u ovoj je studiji kompresorska lopatica s pukotinama, izrađena od nehrđajućeg čelika, izložena djelovanju visokonaponske pulsne struje te je proučeno obnavljanje materijala pod utjecajem Jouleove topline i efekta strujanja.

Ključne riječi

Pukotina, pulsna struja, obnavljanje, zacjeljivanje pukotina

a Tianjin Key Laboratory of Information Sensing

\& Intelligent Control, Tianjin University of Technology and Education, Hexi District, Tianjin, 300 222, Kina

b Architectural Engineering Department, Wenzhou Vocational \& Technical College, Wenzhou, Zhejiang 325 000, Kina
Izvorni znanstveni rad Prispjelo 27. veljače 2017. Prihvaćeno 9. svibnja 2017. 